WISSENSCHAFTSZENTRUM BERLIN FÜR SOZIALFORSCHUNG

SOCIAL SCIENCE RESEARCH CENTER BERLIN

Benny Geys * Jan Vermeir **

Party Cues and Yardstick Voting

* WZB

${ }^{* *}$ Vrije Universiteit Brussel

SP || $2008-05$

February 2008

ISSN Nr. $0722-6748$

Research Area

Markets and Politics

Research Unit

Market Processes and Governance
Schwerpunkt

Märkte und Politik

Abteilung

Marktprozesse und Steuerung 
Zitierweise/Citation:

Benny Geys and Jan Vermeir, Party Cues and Yardstick

Voting, Discussion Paper SP II 2008 - 05,

Wissenschaftszentrum Berlin, 2008.

Wissenschaftszentrum Berlin für Sozialforschung gGmbH,

Reichpietschufer 50, 10785 Berlin, Germany, Tel. (030) 25491 - 0

Internet: www.wzb.eu 


\title{
ABSTRACT
}

\section{Party Cues and Yardstick Voting}

\author{
by Benny Geys and Jan Vermeir
}

Politicians within any given party generally exhibit a degree similarity in terms of (political) viewpoints. Moreover, they are often constrained to follow general party lines on certain policy issues. Finally, they may be more likely to mimic one another than politicians from another party. Hence, parties provide important cues on how politicians will act once elected. The present paper assesses the implications of such party cues for the traditional model of yardstick voting (where voters use what they observe in neighbouring jurisdictions to judge the performance of their incumbent). It is shown that the information content of what happens in neighbouring jurisdictions differs depending on whether or not the same party governs this jurisdiction. More specifically, we find that voters might still take neighbouring jurisdictions into account, but should distinguish between jurisdictions where the same or a different party is in power. The results of the model are in line with recent empirical observations in Sweden and the United States.

Keywords: Yardstick voting, spatial interaction, party labels, party cues

JEL Classification: D72, H3O, H77

\section{ZUSAMMENFASSUNG}

\section{Parteien und 'Yardstick'-Wählen}

Politiker einer beliebigen Partei zeigen gewöhnlich Ähnlichkeiten bezüglich (politischer) Ansichten. Zudem sind sie in bestimmten Politikfeldern oft abhängig von Grundsätzen ihrer Partei. Letztlich übernehmen sie Standpunkte eher untereinander als von Politikern anderer Parteien. Daher liefern Parteien wichtige Hinweise wie Politiker nach ihrer Wahl handeln werden. Das vorliegende Papier beurteilt die Auswirkungen solcher Informationen über die Partei auf das bekannte „Yardstick Voting“ Modell (Wähler nutzen ihre Beobachtungen aus benachbarten Regionen zur Beurteilung ihrer eigenen Regierung). Es wird gezeigt, dass der Informationsgehalt der Ereignisse in Nachbarregionen stark davon abhängt, ob dieselbe Partei die Regierung stellt. Genauer gesagt, Wähler können andere Regionen bei ihren Entscheidungen berücksichtigen, jedoch sollten sie zwischen solchen mit derselben und mit einer anderen Partei in der Regierungsverantwortung differenzieren. Die Ergebnisse des Modells decken sich mit jüngsten Beobachtungen in Schweden und den Vereinigten Staaten. 


\section{Introduction}

Both economists and political scientists have stressed that political parties tend to develop a reputation for particular policy positions (e.g., Wittman, 1989, 1995; Aldrich, 1995; Jones and Hudson, 1998; Lupia and McCubbins, 1998; Müller, 2000). As a consequence, the party's name becomes a cue for the policy decisions its politicians (or 'members') are likely to resort to once elected, and thus - in marketing terms - can be seen as a 'brand name'. Once established, these party brand names provide low-cost information to voters about the politicians associated with these parties (see Snyder and Ting, 2002, 2003 and references therein). Specifically, they indicate to the voter "how the coalition of its members will behave" (Wittman, 1995, 21). Membership of a given party is therefore "one of the signals that voters use when estimating the 'quality' of political representatives" (Jones and Hudson, 1998, 187; see also Caillaud and Tirole, 2002; Poutvaara and Takalo, 2007).

Party brand names not only provide valuable cues about politicians to voters, but may also lead politicians to self-select into parties that share their preferences. Reversely, political parties may use "screening mechanisms to select candidates with fairly homogeneous personality traits" (Jones and Hudson, 1998, 184). Both elements serve to reinforce the similarity or "cohesion" in terms of (political) viewpoints that exists between politicians belonging to the same party (Hazan, 2003, 1). Finally, the need to preserve the strength of the brand name - which may be important for electoral considerations - creates strategic incentives for and instils constraints on party members (especially for those pursuing a political career within the party) (e.g., Caillaud and Tirole, 2002; Crutzen, 2004). That is, politicians are often required to follow party lines on certain issues. Such party discipline makes that "parties matter, even once preferences have been taken into account" (Hazan, 2003, 1).

While all this does not mean that parties are unitary actors in which any politician is a mirror-image (or perfect substitute) of the other politicians of the party (as commonly assumed in early Political Economy models such as Downs, 1957; Barro, 1973; Ferejohn, 1986) it does imply that politicians within any given party are to some extent interchangeable and tend to follow similar policies. ${ }^{1}$ Obviously, other arguments could be proposed to explain this correspondence between the policies of politicians within the same party. While we do not intend to list all of them here, two are worth mentioning more explicitly. First, it is easier for politicians of the same party to collude and form a political 'cartel'. Such collusion will, similar to the arguments above, induce similarity in policies pursued by politicians of the same party. Second, one could argue that politicians of the same party are more likely to engage in a 'mimicking' of each other's policies, even when they are not made to follow the same policies through party discipline. The reason is that they (inherently) feel drawn to the same

Ashworth et al. (2006) and Foucault et al. (2007), among others, find supportive empirical evidence for the contention that politicians of the same party are more likely to take similar decisions. The former analyse the diffusion of an environmental tax across the Flemish municipalities between 1990 and 1999 and show that "the closer is the ideology of those authorities that have adopted the tax to the ideology of a given authority, the more likely it is that the authority will adopt the tax" (Ashworth et al., 2006, 242). The latter assess public spending interactions in France over the period 1983-2002 and uncover that "when facing a common shock, incumbents with the same partisan affiliation react in the same way in terms of primary, operating and investment expenditure" (Foucault et al., 2007, 16). 
policies as well as are able to obtain more information on the content and implementation strategy of particular policies from other party members. ${ }^{2}$

This paper analyses the consequences of such 'party effects' in a model of yardstick voting. Previous theoretical models of yardstick voting (e.g., Besley and Case, 1995; Revelli, 2002) argue that voters - being imperfectly informed about the competency and/or honesty of their government - can benefit from an informational spill-over induced by what happens in neighbouring jurisdictions. This use of neighbouring jurisdictions as a yardstick enables them, under certain conditions, to learn more about their own incumbent's quality (e.g., Salmon, 1987, 2005; Besley and Case, 1995). However, despite the clear structuring importance of political parties in real life, partisanship is completely ignored in previous models of this kind (Revelli, 2006, conjectures about the potential importance of politics in models of yardstick voting but does not rigorously follow up on this idea). The present paper takes a first step to address this issue and shows that allowing for partisan effects entails that the use of neighbouring jurisdictions as a yardstick is no longer straightforward. The reason is that the information content of what occurs in neighbouring jurisdictions varies when incumbents are from the same or different parties. Specifically, our model indicates that high taxation levels in neighbouring jurisdictions have a positive effect on the incumbent's vote when the neighbouring jurisdiction is governed by a politician from a different party. When the incumbents in both jurisdictions are from the same party, however, taxation levels in neighbouring jurisdictions can have a positive or negative effect on the vote (or no effect at all). Hence, a distinction should be made between neighbouring jurisdictions based on whether the same or a different party is in power. These findings are in line with recent empirical observations on voting in Swedish municipalities (Ågren, 2005) and the United States (Johnson, 2006).

\section{The model}

To facilitate comparisons with the existing literature, we adapt the model of yardstick voting brought forward by Revelli (2002). We focus on a setting with two parties and two jurisdictions ( $i$ and $j$ ), which are each others' neighbours. ${ }^{3}$ While most of the empirical spatial econometrics literature defines neighbourliness in a purely geographical sense (Brueckner, 2003; Geys, 2006; Van Parys and Verbeke, 2007), our theoretical approach allows for more general definitions (e.g. based on similarity in socio-economic characteristics; see Baicker, 2005). The incumbent government in each jurisdiction is responsible for the provision of a purely local public good. While interjurisdictional spillovers have been advanced as a possible explanation of spatial patterns in fiscal policies (see, e.g., Kelejian and Robinson, 1993; Solé-Ollé, 2006; Werck et al., 2008), the present model assumes the absence of such spillovers. A similar assumption was introduced by, among others, Revelli (2002) and allows us to study the spatial interactions that emerge solely as a consequence of an informational spillover between jurisdictions.

\footnotetext{
We are grateful to Daniel Sturm and Ivo Bischoff, respectively, for suggesting these alternatives.

The introduction of multiple neighbours makes the model less tractable as, for example, appropriate spatial weights should be assigned to the various neighbours. Hence, we limit ourselves to the simple set-up with only two jurisdictions to more clearly illustrate the effect of party cues (cfr. Revelli, 2002; Rork, 2003). Still, clearly, adding additional jurisdictions is one potential extension to our simple model - and the ensuing need for adequate weighing schemes is obviously of crucial importance in empirical applications.
} 
The cost - in terms of taxation - of the local public good (c) is determined by three elements. ${ }^{4}$ The first is the price at which the local government buys this good at the national market (p). This price is common knowledge and, for simplicity, assumed constant over time. The second element is a cost shock specific to each jurisdiction $(\theta)$. This is a stochastic variable over which the local government has no control and which is taken from an unbounded normal distribution with $\mathrm{E}(\theta)=0$ and $\operatorname{Var}(\theta)=\sigma_{\theta}^{2}$ (these shocks are assumed to be uncorrelated over time). Finally, the cost of the local public good is influenced by the politician's inherent 'quality' (which affects the policies the incumbent implements, the approach she takes towards provision of the public good, and so on). These policies can increase or decrease the total cost of the public good with a value $\mathrm{q}$, whereby $\mathrm{q}$ is drawn from an unbounded normal distribution with $\mathrm{E}(\mathrm{q})=0$ and $\operatorname{Var}(\mathrm{q})=\sigma_{q}^{2}$ (crucial in our model is that this candidate 'quality' is not iid, as discussed more explicitly below). ${ }^{5}$ Hence, we can write the cost of the public good in jurisdiction $i$ at time $t$ as:

$$
c_{i t}=p+\theta_{i t}-q_{i}
$$

Given that voters only observe the total cost of public goods provision $\left(\mathrm{c}_{\mathrm{it}}\right)$ and the national market price $p$, they are unable to differentiate between the effect of cost shocks and that of the politician's quality. Yet, if cost shocks in jurisdictions $\mathrm{i}$ and $\mathrm{j}$ are positively correlated (i.e. $\rho=\operatorname{corr}\left(\theta_{i t}, \theta_{j t}\right)>0$ ), information about the cost of local public goods in neighbouring jurisdictions helps to uncover the 'quality' of one's own incumbent (since it provides some information on whether this politician's approach to public good provision increased or decreased the total cost $\mathrm{c}$ ). This correlation is crucial to previous models of yardstick voting. Indeed, if cost shocks are not correlated, nothing can be gained by looking at neighbouring jurisdictions (Besley and Case, 1995; Revelli, 2002).

Still, as argued above, politicians of the same political party are likely to have similar preferences (Hazan, 2003) and be relatively homogeneous due to party's screening of candidate members (Jones and Hudson, 1998). Moreover, they might have an incentive to follow party guidelines (e.g., Jones and Hudson, 1998; Caillaud and Tirole, 2002; Crutzen, 2004) or be more easily able to 'collude' with neighbours' incumbents when these are from the same party. These features imply that politicians are likely to implement similar policies (with comparable consequences in terms of the cost of the public good provided) when they are from the same party. In terms of the present model, this implies that, as mentioned above, $\mathrm{q}$ is not iid. More specifically, this partisan effect can be modelled by assuming a joint probability distribution in which the q's of politicians of the same party have a positive correlation (whereas the q's of politicians from different parties are independent). That is, the quality of a politician of party $\mathrm{A}$ in jurisdiction $\mathrm{i}$ and a politician of party $\mathrm{A}$ in jurisdiction $\mathrm{j}$ follows a joint

\footnotetext{
Note that the provision of public goods is normalised to one (cfr. Besley and Case, 1995). Hence, lower cost of provision can be interpreted as higher government efficiency.

5 Politician's 'quality' is exogenous in our model. This contrasts to recent efforts attempting to explain the (lack of) competence and honesty of elected officials using a citizen-candidate framework (e.g., Besley, 2004; Caselli and Morelli, 2004; Messner and Pollborn, 2004; Poutvaara and Takalo, 2007) and endogenizing quality might provide an interesting extension to future research.
} 
normal distribution with mean 0 , standard deviation $\sigma_{q}^{2}$ and positive covariance. Representing this correlation between politicians in a given party as $\eta$, we thus assume that $\eta>0$ when politicians are of the same party while $\eta=0$ when they belong to different parties. ${ }^{6}$ As the draws of $q$ for politicians from the same party therefore are not fully independent (though these draws are independent across parties), we introduce some form of cross-jurisdictional political path-dependence into the yardstick voting model.

Compared to the 'standard' model of yardstick voting (e.g., Besley and Case, 1995; Revelli, 2002), the presence of a correlation in the behavior of politicians from the same party implies that two cases should be distinguished: incumbents in the two jurisdictions are from the same party or incumbents in both jurisdictions are from different parties. Before we turn to the analysis of these two cases, let us consider the timing of the model. At the beginning of period $t$, a government is established in both jurisdictions. Given that we focus on a two-period model, these are new governments (i.e. they have not been in office in a previous term and no historical information is available about them). ${ }^{7}$ Then, a cost shock materializes and voters observe the realisations of the total cost of public good provision in both jurisdictions ( $\mathrm{c}_{\mathrm{it}}$ and $\mathrm{c}_{\mathrm{jt}}$ respectively). They use this information to update their beliefs about their incumbent (i.e. about the value of q) (and, if possible, the opposition candidate). The (ex post) conditional expectation of q given the outcomes observed in the first period (i.e. $E\left(q \mid c_{i t}, c_{j t}\right)$ is then a weighted average of the ex ante mean of quality (here assumed to be 0 ) and period 1 costs of public goods provision (in both jurisdictions) - with the weight on the latter term depending on the relative variance of quality and the random shock $(\theta)$ (see also Meyer and Vickers, 1997, for a similar approach in a different setting). Based on these updated beliefs, they decide to re-elect their current incumbent or to replace him/her by an opposition candidate.

\section{CASE 1: Incumbents in both jurisdictions are from the same party}

Let us assume a stochastic voting rule under which the probability that a given voter casts a ballot in favour of the incumbent $\left(\mathrm{S}_{\mathrm{it}}\right)$ can be written as (see Revelli, 2002):

$$
S_{i t}=\operatorname{Pr}\left\{E\left(c_{i, t+1}^{O}\right)-E\left(c_{i, t+1}^{I} \mid c_{i t}, c_{j t}\right)+\alpha_{i t}>0\right\}
$$

where $\mathrm{E}$ is the expectations operator, superscripts $\mathrm{I}$ and $\mathrm{O}$ refer to the incumbent and opposition candidate respectively and $\alpha_{i t}$ is a zero mean random term that is iid across voters and (for mathematical convenience) follows a logistic distribution. ${ }^{8}$ Alternatively, one might also impose a deterministic voting rule in which incumbents

6 An alternative way to specify this intra-party correlation is to assume that q consists of two parts: a politician-specific element (which can be assumed iid) and a party-specific element. We are grateful to Johannes Münster for this suggestion.

7 Clearly, the model can be extended by regarding a longer time frame. This would allow for, say, the possibility that an incumbent's quality increases with experience (i.e. with the number of periods in office). We abstain from such extensions at present and concentrate on the most basic set-up to illustrate the effect of politicians' intra-party similarity.

8 One might also allow for a non-zero mean of $\alpha_{i t}$ to represent, for example, an incumbency advantage (cfr. Grossman and Helpman, 1996; Konrad, 2002; Chaturvedi and Münster, 2005; Mehlum and Moene, 2006). This extension does not affect our basic findings. 
are re-elected with probability one if the expected level of government efficiency under the incumbent in the next period is higher than or equal to that expected under the opposition candidate (and zero otherwise). However, this presumes that the voter's decision is solely driven by the efficiency of public service provision. This is unlikely to hold in reality. Hence, we rely on the stochastic approach rendered in equation (2).

Essentially, equation (2) states that, for a given realisation of the random term $\left(\alpha_{i t}\right)$, any given voter has a higher probability of voting for the present incumbent if the candidate's (updated) expected cost of providing the public good - given the cost realisation in both jurisdictions at time $\mathrm{t}-$ is smaller than the expected cost under the opposition party's candidate. Note that multiplication of this probability of voting for the incumbent with the number of voters gives the expected number of votes for the incumbent in jurisdiction $i$. Hence, this expression at the same time represents the vote share of the incumbent.

Now, since the cost shock $(\theta)$ and the national price of the public good (p) are unaffected by which party is in power, equation (2) can be reformulated as:

$$
S_{i t}=\operatorname{Pr}\left\{E\left(q_{i}^{O}\right)-E\left(q_{i}^{I} \mid c_{i t}, c_{j t}\right)+\alpha_{i t}<0\right\}
$$

When the incumbents in both jurisdictions are from the same party, voters have no additional information to update their beliefs about the opposition candidate. Hence, $\mathrm{E}\left(q_{i}^{O}\right)$ is simply the average value, which, given the assumptions above, is zero. The voters' updated beliefs concerning the incumbent $-\mathrm{E}\left(q_{i}^{I} \mid c_{i t}, c_{j t}\right)$ - on the other hand can be written as (DeGroot, 1970, 167; see also Theil, 1971, 188-189; Meyer and Vickers, 1997):

$$
E\left(q_{i}^{I} \mid c_{i t}, c_{j t}\right)=\beta\left(c_{i t}-p\right)+\delta\left(c_{j t}-p\right)
$$

Substituting this into equation (3) leads to:

$$
S_{i t}=\operatorname{Pr}\left\{\alpha_{i t}<\beta\left(c_{i t}-p\right)+\delta\left(c_{j t}-p\right)\right\}
$$

As $\alpha_{i t}$ follows a logistic distribution, we can rewrite $\mathrm{S}_{\mathrm{it}}$ as (cfr. Revelli, 2002):

$$
S_{i t}=\frac{\exp \left[\beta\left(c_{i t}-p\right)+\delta\left(c_{j t}-p\right)\right]}{1+\exp \left[\beta\left(c_{i t}-p\right)+\delta\left(c_{j t}-p\right)\right]}
$$

Or, after rearranging terms and taking natural logarithms:

$$
s_{i t}=h_{t}+\beta \cdot c_{i t}+\delta \cdot c_{j t}
$$

Whereby $s_{i t} \equiv \log \left[S_{i t} / 1-S_{i t}\right]$ and $h_{t} \equiv-(\beta+\delta) p$. The expected vote share of the incumbent thus depends both on the tax burden (or, given the normalisation of public goods provision in the model, the efficiency) in the own jurisdiction and that in the 
neighbouring jurisdiction. The relative weights placed on each of these $(\beta$ and $\delta$ respectively) can be determined through a standard application of Bayesian updating methods (DeGroot, 1970; Theil, 1971; Meyer and Vickers, 1997). This reveals that:

$$
\begin{gathered}
\beta=\frac{\tau(-1+\eta \kappa)}{1-\kappa^{2}} \\
\delta=\frac{\tau(\kappa-\eta)}{1-\kappa^{2}}
\end{gathered}
$$

Where $\tau=\frac{\sigma_{q}^{2}}{\sigma_{q}^{2}+\sigma_{\theta}^{2}}$ is a measure of the relative variances of politicians' quality (q) and the cost shock $(\theta) . \quad \kappa$ can be thought of as the 'cross section' correlation between $c_{i}$ and $c_{j}$ (Meyer and Vickers, 1997) and equals:

$$
\kappa \equiv(1-\tau) \rho+\tau . \eta
$$

We are now in a position to determine how, and under which conditions, government efficiency in the own and neighbouring jurisdiction affects the re-election chances of the incumbent government. Firstly, from equation (8), it can be seen that $\beta<0$, such that high cost of public goods provision in the own jurisdiction always translates in a loss of votes for the incumbent government (and has a negative effect on his/her probability of re-election). Secondly, the effect of the tax burden in neighbouring jurisdictions (represented by the parameter $\delta$ ) is not a priori clear. The effect depends on the relative size of the correlations between the cost shocks in both jurisdictions $(\rho)$ and the correlation between politicians of the same party $(\eta)$. Essentially, there are three possibilities. In the first case, the correlation of the cost shocks is larger than the correlation between politicians within a party $(\rho>\eta)$. From equations (9) and (10), it can be gauged that under this condition $(\delta>0)$. Hence, even though politicians of the same party are likely to take similar actions, the neighbouring tax burden still reveals mostly information about the size of the cost shock. In fact, as in the 'standard' yardstick voting model (e.g., Besley and Case, 1995; Revelli, 2002), a high tax burden in the neighbouring locality suggests to voters that the cost shock was high, and therefore leads to a higher vote share for the incumbent in jurisdiction i. Note that when $\eta=0$ our model reduces to the model of Revelli (2002). In that setting, the tax burden of the neighbours always has a positive effect on the vote share.

When $\rho<\eta$, the correlation between politicians of the same party exceeds the correlation in cost shocks. In this case, high costs in the neighbouring jurisdiction inform the voter that the incumbent in the neighbouring jurisdiction increases the cost of the public good. But since politicians within the same party are correlated, this indicates that one's own incumbent is probably one of that same breed. Consequently, a high cost in the neighbouring jurisdiction has a negative effect on the vote share for the incumbent. From equations (9) and (10) it follows that $\delta$ now takes on a negative value. In the extreme case where parties are assumed to be unitary actors in which all politicians are fully interchangeable (cfr. Barro, 1973; Downs, 1957; Ferejohn, 1986) ${ }^{9}$,

9 One might, for example, think of very strict party discipline. 
this condition will hold with (near) certainty (since $\rho<\eta=1$ ). Hence, in such a setting, high costs of the public good in the neighbouring jurisdiction certainly lead to electoral retribution for the incumbent.

When both correlations are equal $\rho=\eta$, the tax burden in neighbouring jurisdictions is uninformative. It is equally likely to derive from a high (low) cost shock or a costincreasing of cost-decreasing behaviour of the politician in jurisdiction $\mathrm{j}$. Both elements have opposite effects on the vote share of the incumbent in jurisdiction $i$ and cancel each other out (i.e. $\delta=0$ ).

\section{CASE 2: Incumbents in both jurisdictions are from different parties}

When the incumbents in jurisdictions $\mathrm{i}$ and $\mathrm{j}$ are from different parties, the opposition candidate in jurisdiction $i$ is of the same party as the incumbent in the neighbouring jurisdiction. Neighbours' policies then not only reveal information about the likelihood of a high or low cost shock, but also about the opposition candidate. Hence, compared to Case 1, both the expression for the expected $\mathrm{q}$ of the incumbent and the opposition candidate differ. Starting with the former, this can, as before (see equation (4)), be written as:

$$
E\left(q_{i}^{I} \mid c_{i t}, c_{j t}\right)=\beta\left(c_{i t}-p\right)+\delta\left(c_{j t}-p\right)
$$

However, given that incumbents are not from the same party (i.e. $\eta=0$ ), the weights voters attach to the information obtained from the public good's cost in both the own and the neighbouring jurisdiction change. More specifically, we now get that:

$$
\begin{aligned}
& \beta=\frac{-\tau}{1-\rho^{2}(1-\tau)^{2}} \\
& \delta=\frac{\tau(1-\tau) \rho}{1-\rho^{2}(1-\tau)^{2}}
\end{aligned}
$$

The expected q of the opposition candidate is now correlated with that of the incumbent in the neighbouring jurisdiction (as these are from the same party and thus likely to take similar decisions). Hence, her expected q depends on the tax burden of the neighbouring jurisdiction (as well as that in the own jurisdiction). Specifically, it can be shown to equal:

$$
E\left(q_{i}^{O} \mid c_{j t}\right)=\eta \cdot \delta\left(c_{i t}-p\right)+\lambda\left(c_{j t}-p\right)
$$

with $\lambda=-\eta \cdot \tau$

Introducing these results in equation (3) and performing appropriate rearrangements (see equations (6) and (7)), we obtain:

$$
s_{i t}=h_{t}+(\beta-\eta . \delta) c_{i t}+(\delta-\lambda) c_{j t}
$$


whereby $s_{i t} \equiv \log \left[S_{i t} / 1-S_{i t}\right], h_{t} \equiv-(\beta+\delta-\lambda) p$ and $\beta, \delta$ and $\lambda$ are defined as in equations (12), (13) and (14) respectively. Given that both $\tau$ and $\rho$ are positive and smaller than one, equation (12) illustrates that $\beta<0$. The own jurisdiction's tax burden again has a negative effect on the incumbent's vote share (and re-election odds). For the same reason, equation (13) shows that $\delta>0$ such that the tax burden in the neighbouring jurisdiction has a positive effect on the incumbent's vote share. Note, moreover, that when politicians of the same party become increasingly likely to follow similar policies (i.e. $\eta$ becomes larger), a high tax burden in the neighbouring jurisdiction weighs heavier on the opposition candidate in the own jurisdiction (see equation (14)). This supplements the positive effect low efficiency in the neighbouring jurisdiction has on the expected quality of the own incumbent. Therefore, the positive effect of the tax burden in the neighbouring jurisdiction on the incumbent's vote share is stronger here than under case 1

\section{Discussion and conclusion}

Politicians within any given party are (albeit imperfect) substitutes of one another. This proposition is supported by the observations that: (a) politicians within any given political party tend to have similar policy preferences (Jones and Hudson, 1998; Hazan, 2003), (b) they tend to be constrained by intra-party disciplining devices (Caillaud and Tirole, 2002; Crutzen, 2004) in order to maintain the party's reputation or brand name (Wittman, 1989, 1995; Jones and Hudson, 1998) and (c) politicians within the same party might more easily mimic one another across jurisdictions. Importantly, the ensuing correlation between actions of politicians of the same party has considerable consequences for the standard model of yardstick voting (e.g., Besley and Case, 1995; Revelli, 2002) where voters use neighbouring jurisdictions as a yardstick to judge the quality of their incumbent. In fact, the information content of what occurs in neighbouring jurisdictions differs depending on whether or not the same party governs both jurisdictions. Specifically, low efficiency (i.e. high costs for a given level of public goods provision) in neighbouring jurisdictions is good news for local politicians' reelection chances only when the neighbouring jurisdiction is governed by a politician from a different party. When the incumbents in both jurisdictions are from the same party, tax levels in neighbouring jurisdictions can have a positive or negative effect on the incumbent's vote (or no effect at all). Hence, our results illustrate that voters should distinguish between jurisdictions where the same or a different party is in power.

Recent empirical evidence on voter behaviour in Swedish municipalities is in line with this core prediction of our model. Indeed, Ågren (2005) tests whether Swedish voters behave differently with respect to the tax rates set in neighbouring municipalities depending on whether these are governed by the same or a different party. The Swedish setting provides an ideal case for such an analysis given that there are essentially two party blocs (i.e. left and right) - allowing a clear designation of the political colour of the local governments. The results illustrate that voters are significantly affected in their vote decision by neighbouring municipalities' fiscal policies only when these are governed by politicians from the opposing political bloc. Policies in neighbouring municipalities with the same political constellation in power do not significantly affect election results in the 'home' municipality. Our model provides an explanation for such behaviour by arguing that - in the presence of intra-party similarities between 
candidates - taxes in neighbouring jurisdictions are likely to be more informative about local politician's quality when they are levied by the opposite political bloc.

Also, focusing on gubernatorial election results in US counties over the period 19602000, Johnson (2006) finds some support for our main result. Indeed, assessing tax revenue and tax rate changes in the US, she finds evidence for yardstick voting only under "mixed" political control across neighbouring jurisdictions ("mixed" in the sense that the political colour of the neighbouring governors differs). That is, the incumbent's gubernatorial vote share is higher (lower) than what can be expected based on the 'average' vote share of his/her party in the region when the tax burden decreased (increased) relative to neighbouring jurisdictions and the governor in the neighbouring jurisdiction is of the opposite political party than the one in the home jurisdiction. ${ }^{10}$ Hence, though in general there is "only limited evidence in support of yardstick competition" (Johnson, 2006, 1), her findings clearly provide some evidence in line with the idea that party labels matter for yardstick voting.

10 One important exception is to be noted. In contrast to the results under total tax revenues and tax rate changes, the results for income tax liabilities in the higher income tax brackets (i.e. above \$80,000) indicate that yardstick voting appears limited to situation where both governors are Democrat. Though an interesting finding and compatible with the present model, it is not immediately clear to us why income taxation should be different from other taxes in this respect. 


\section{Acknowledgments}

The authors are grateful to an anonymous referee, participants of the $1^{\text {st }}$ World Public Choice Societies Meeting in Amsterdam (the Netherlands, March/April 2007), the WZB Conference on "New Perspectives on Fiscal Federalism" in Berlin (Germany, October 2007) and Ivo Bischoff, Massimo Bordignon, Jan Brueckner, Marie-Laure Breuillé, Randall Holcombe, Marc Jegers, Sebastian Kessing, Kai A. Konrad, Johannes Münster, Florian Morath, Robert Nuscheler, Brian Roberson, Pierre Salmon, Albert Solé-Ollé, Enrico Spolaore, Daniel Sturm, Craig Volden and Barry Weingast for helpful suggestions and discussions. Jan Vermeir gratefully acknowledges financial support of the FWO-Vlaanderen. The usual caveat applies. 


\section{References}

Ågren, H., 2005. Essays on Political Representation, Electoral Accountability and Strategic Interactions. Department of Economics, Uppsala University, Uppsala.

Aldrich, J.H., 1995. Why parties?: The origin and transformation of political parties in America. Chicago University Press: Chicago.

Ashworth, J., Geys, B., Heyndels, B., 2006. Determinants of tax innovation: The case of environmental taxes in Flemish municipalities. European Journal of Political Economy $22(1), 223-247$.

Baicker, K., 2005. The spillover effects of state spending. Journal of Public Economics 89, 529-544.

Barro, R., 1973. The control of politicians: An economic model. Public Choice 14, 1942.

Besley, T., 2004. Paying politicians: Theory and evidence. Journal of the European Economic Association 2, 193-215.

Besley, T., Case, A., 1995. Incumbent behavior: Vote seeking, tax setting and yardstick competition. American Economic Review 85(1), 25-45.

Brueckner, J., 2003. Strategic interaction among governments: An overview of empirical studies. International Regional Science Review 26(2), 175-188.

Caillaud, B., Tirole, J., 2002. Parties as political intermediaries. Quarterly Journal of Economics 117, 1453-1489.

Caselli, F., Morelli, M., 2004. Candidate quality. Journal of Public Economics 88, 759782.

Chaturvedi A., Münster, J., 2005. Long live the King? On dictatorship and development, WZB Berlin, mimeo.

Crutzen, B.S.Y., 2004. Intra-party discipline, rent extraction and electoral rules. Erasmus University Rotterdam, mimeo.

DeGroot, M.H., 1970. Optimal Statistical Decisions. McGraw-Hill: New York.

Downs, A., 1957. An Economic Theory of Democracy. Harper and Row: New York.

Ferejohn, J., 1986. Incumbent performance and electoral control. Public Choice 50(1-2), $5-25$.

Foucault, M., Madiès, T., Paty, S., 2007. Public spending interactions and local politics: Empirical evidence from French municipalities. Presented at the $1^{\text {st }}$ World Public Choice Societies Meeting, Amsterdam, April 2007. 
Geys, B., 2006. Looking across borders: A test of spatial policy interdependence using local government efficiency ratings. Journal of Urban Economics 60(3), 443-462.

Grossman, G.M., Helpman, E., 1996. Electoral competition and special interest politics. Review of Economic Studies 63, 265-286.

Hazan, R.Y., 2003. Does cohesion equal discipline? Towards a conceptual delineation. Journal of Legislative Studies 9(4), 1-11.

Johnson, L., 2006. Yardstick competition: An empirical investigation using state taxes and media markets. MIT, mimeo.

Jones, P., Hudson, J., 1998. The role of parties: An analysis based on transaction costs. Public Choice 94, 175-189.

Kelejian, H., Robinson, D., 1993. A suggested method of estimation for spatial interdependent models with autocorrelated errors and an application to a country expenditure model. Papers in Regional Science 72(3), 297-312.

Konrad, K., 2002. Investment in the absence of property rights: The role of incumbency advantage. European Economic Review 46(8), 1521-1537.

Lupia, A., McCubbins, M.D., 1998. The Democratic Dilemma: Can Citizens learn what they need to know? Cambridge University Press, Cambridge.

Mehlum, H., Moene, K., 2006. Fighting against the odds. Economics of Governance 7(1), 75-87.

Messner, M., Pollborn, M.K., 2004. Paying politicians. Journal of Public Economics 88, 2423-2445.

Meyer, A., Vickers, J., 1997. Performance comparisons and dynamic incentives. Journal of Political Economy 105(3), 547-581.

Müller, W.C., 2000. Political parties in parliamentary democracies: Making delegation and accountability work. European Journal of Political Research 37, 309-333.

Poutvaara, P., Takalo, T., 2007. Candidate quality. International Tax and Public Finance 14, 7-27.

Revelli, F., 2002. Local taxes, national politics and spatial interactions in English district election results. European Journal of Political Economy 18, 281-299.

Revelli, F., 2006. Performance rating and yardstick competition in social service provision. Journal of Public Economics 90, 459-475.

Rork, J.C., 2003. Coveting thy neighbour's taxation. National Tax Journal 56(4), 775787. 
Salmon, P.G., 1987. Decentralization as an incentive scheme. Oxford Review of Economic Policy 3(2), 24-43.

Salmon, P.G., 2005. Horizontal competition among governments. Université de Bourgogne, mimeo.

Snyder, J.M., Ting, M.M., 2002. An informational rationale for political parties. American Journal of Political Science 46(1), 90-110.

Snyder, J.M., Ting, M.M., 2003. Roll calls, party labels and elections. Political Analysis 11(4), 419-444.

Solé Ollé, A., 2006. Expenditure spillovers and fiscal interactions: empirical evidence from local governments in Spain. Journal of Urban Economics 59(1), 32-53.

Theil, H., 1971. Principles of Econometrics. John Wiley and Sons, New York.

Van Parys, S., Verbeke, T., 2007. Tax competition among Belgian municipalities: A multi-dimensional battle? Presented at the $1^{\text {st }}$ World Spatial Econometrics Association Meeting, Cambridge (UK), July 2007.

Werck, K., Heyndels, B., Geys, B., 2008. The Impact of 'Central Places' on Spatial Spending Patterns: Evidence from Flemish Local Government Cultural Expenditures, Journal of Cultural Economics. Forthcoming.

Wittman, D., 1989. Why democracies produce efficient results. Journal of Political Economy 97(6), 1395-1424.

Wittman, D., 1995. The Myth of Democratic Failure: Why Political Institutions are Efficient. Chicago University Press, Chicago. 